\author{
Al-wardah: Jurnal Kajian Perempuan, Gender dan Agama \\ Volume: 12 Nomor: 2 \\ ISSN: 1907-2740, E-ISSN: 2613-9367 \\ DOI: $\mathrm{xxx} \mathrm{xxxx} \mathrm{xxxx}$
}

\title{
BAHAYA RADIKALISME DAN KEKERASAN EKSTRISMISME
}

\author{
Musdah Mulia \\ Universitas Islam Negeri Syarif Hidayatullah Jakarta, Indonesia \\ m-mulia@indo.net.id
}

\begin{abstract}
Abstrak
Maraknya konflik kekerasan berbasis agama yang terjadi pasca reformasi hingga saat ini, merupakan gumpalan konflik lama yang baru menemukan ruangnya. Pandangan fundamentalisme sangat membahayakan kehidupan perempuan. Sebab, umumnya pandangan mereka adalah menolak prinsip keadilan dan kesetaraan gender, menolak KB dan semua unsurnya, menolak pendidikan seksual dan kesehatan reproduksi, menolak penderita HIV/Aids dan kelompok Odha serta menganggap kutukan, menolak perlindungan thd korban perkosaan, menolak perlindungan terhadap pekerja seks komersial. Masyarakat muslim yang mempertahankan fundamentalisme memiliki kecenderungan memanipulasi dan memanfaatkan ajaran Islam untuk melegitimasi kekuasaan patriarkhi dan mengucilkan perempuan dari ruang publik. Apabila mengamati secara umum hak-hak sipil dan politik kaum perempuan di bawah berbagai rezim Islam di dunia ini, terlihat secara kasat mata bahwa mereka sungguh membelenggu hak-hak sipil dan politik kaum perempuan.
\end{abstract}

Kata kunci: Radikalisme, Perempuan

\begin{abstract}
The rise of religious-based violent conflict that occurred after the reformation to date, is a lump of old conflict that just found its space. The view of fundamentalism is very dangerous to the lives of women. Because, in general, their views are rejecting the principles of justice and gender equality, rejecting family planning and all its elements, rejecting sexual education and reproductive health, rejecting HIV / AIDS sufferers and people with HIV and assuming curses, refusing protection against rape victims, refusing protection against commercial sex workers. Muslim societies who maintain fundamentalism have a tendency to manipulate and utilize Islamic teachings to legitimize patriarchal power and exclude women from the public sphere. When observing in general the civil and political rights of women under various Islamic regimes in the world, it can be seen clearly that they are truly shackling women's civil and political rights.
\end{abstract}


Keywords: Radicalism, Woman.

\section{A. Pendahuluan}

Bangsa Indonesia saat ini dihadapkan pada situasi meningkatnya intoleransi, radikalisme, terorisme dan ekstremisme dengan kekerasan (violent extremism). Berbagai wilayah menunjukkan gejala intoleransi yang mengkawatirkan yang dibarengi meningkatnya politik identitas. Anak-anak muda terpapar informasi keagamaan yang berisi kecurigaan dan kebencian yang cenderung mengingkari atau menentang pemenuhan hak-hak kewarganegaraan terhadap kelompok lain yang tidak disukai, serta membenarkan dan mendukung tindakan atau gerakan radikal.

Harus diakui, dalam era transisi menuju demokrasi, seperti saat ini, labilitas negara diuji dengan beragam peristiwa konflik. Pengalaman sejumlah negara yang melalui masa transisi demokrasi setelah tumbangnya rezim otoriter, tidak serta merta berhasil menjadi negara yang demokratis. Alih-alih berhasil mencapai demokratisasi, yang terjadi malah otoritarianisme baru yang tidak kalah otoriternya dengan rezim sebelumnya. Bahkan dalam struktrur politik yang mapan sekalipun masa transisi akan melahirkan krisis legitimasi sesaat. Bahkan kalau proses transisi tidak dikawal dengan konsolidasi, bukan tidak mungkin krisis legitimasi itu berlangsung abadi. Maraknya konflik kekerasan berbasis agama yang terjadi pasca reformasi hingga saat ini, merupakan gumpalan konflik lama yang baru menemukan ruangnya.

Kejatuhan Orde Baru 1998 memberi jalan bagi demokrasi tumbuh dan berkembang, antara lain ditandai dengan kehadiran partai-partai politik dengan berbagai aliran (Pemilu, 1995). Di Pemilu 1999, ikut bersaing 48 partai politik. Jumlah tersebut sangat fantastis dibanding zaman Orde Baru hanya tiga partai: Golkar, PDI, dan PPP. Sayangnya, kondisi kebebasan, utamanya kebebasan berekspresi di masa ini disalahgunakan oleh kelompok Islam yang cenderung memihak radikalisme.

Pasca pengeboman gedung WTC, terlihat seluruh dunia mengutuk kejadian itu. Salah satu kelompok yang diklaim bertanggungjawab atas aksi tersebut adalah AlQaeda pimpinan Osama Bin Laden. Kejadian ini semakin memperburuk citra Islam di mata dunia. Islam kemudian distigmatisasi sebagai agama teror. Padahal, pandangan Islam sendiri tidak monolitik. Banyak kelompok Islam, khususnya kelompok Islam moderat tidak setuju dengan cara-cara jihad yang dilakukan kelompok Osama Bin Laden (Qadawai, 2001). Menyikapi aksi teror tersebut, setiap negara membuat kebijakan yang berbeda-beda. Amerika, misalnya mengeluarkan kebijakan Perang Melawan Teror yang disebut Patriot Act. Sementara di Indonesia, kebijakan pemerintah pasca bom Bali adalah menerbitkan Peraturan Pemerintah Pengganti Undang-undang (Perppu) No. 1 Tahun 2002 tentang Pemberantasan Terorisme. Lalu, Perppu No. 2 Tahun 2002 tentang penggunaan Perppu No.1 untuk melakukan penyelidikan terhadap 
kasus peledakan bom Bali. Selain itu, pemerintah juga menetapkan JI sebagai organisasi teroris yang bertanggungjawab atas aksi bom Bali. Namun diterbitkannya Perppu ini menurut YLBHI melahirkan banyak kontroversi (Perppu No.1 Tahun 2002).

Dalam perkembangannya, Perppu No. 1 tahun 2002 ini kemudian disahkan menjadi UU No. 15 tahun 2003 tentang Pemberantasan Tindak Pidana Terorisme, dan Perppu No. 2 Tahun 2002 diubah menjadi Undang-undang No. 16 Tahun 2003 (undangUndang No. 16 Tahun 2003). Selain pembentukan undang-undang, pemerintah juga melahirkan Densus 88 pada 2002. Selain membentuk satuan yang bertugas untuk menindak teroris, pemerintah juga pada 2010 membentuk Badan Nasional Penanggulangan Terorisme (BNPT) dengan tugas pokok dan fungsi bidang penanggulangan terorisme.

Dengan ungkapan lain, pemerintah Indonesia memilih jalan pemberantasan terorisme dengan model law-enforcment. Hal ini bisa dilihat dari pembuatan undangundang dan implementasi undang-undang oleh pemerintah. Hampir semua teroris yang tertangkap oleh Densus 88 selalu melalui proses hukum yang berlaku. Menurut Suhadi, kepala BNPT, UU No. 15 Tahun 2003 tentang Pemberantasan Tindak Terorisme menjadi UU yang terlengkap di dunia saat ini, sebab mengandung tiga aspek penting dalam penanggulangan terorisme, yakni pencegahan, penindakan serta perlindungan terhadap korban dan kompensasinya.

\section{B. Pembahasan}

\section{Trend Keterlibatan Perempuan}

Beberapa tahun belakangan, bukti-bukti yang ada menunjukkan bahwa keterlibatan kaum perempuan dalam aksi-aksi teroris terus meningkat. Di negara-negara seperti Jerman, Irlandia dan Italia di Eropa, Peru di Amerika Latin, juga di Gazadan Tepi Barat di Wilayah Pendudukan di Israel/Palestina hingga Rusia/Chechnya, SriLanka, India, Turki, dan lainnya, termasuk yang paling belakangan diIrak dan Yordania, kelompok-kelompok teroris makin lama makin mengandalkan kaum perempuan didalam menjalankan aksi mereka. Mereka menjalankan fungsi-fungsi beragam, di antaranya sebagai informan, kurir, mata-mata, pendidik, perekrut, menjadi pelindung manusia (human shield), atau sekadar menjadi pemuas kebutuhan seks teroris laki-laki yang jelas tak bisa diabaikan.

Sepanjang dua decade terakhir, dengan makin dimanfaatkannya perkembangan teknologi bagi pencapaian tujuan-tujuan terorisme, kaum perempuan juga turut mengelola penerbitan organisasi teroris atau situs-situs organisasi teroris di Internet. 
Perempuan semakin meningkat perannya dalam aksi-aksi terorisme bunuh-diri,yang menjadikan tubuh mereka sebagai senjata mematikan. Menurut Bahrun Naim, pimpinan ISIS asal Indonesia, perlunya mengajak perempuan untuk ikut melakukan aksi teror karena semakin sedikit laki-laki yang bersedia menjadi teroris. Lebih jauh dia mengatakan: "kalau di Suriah aksi amaliyah tidak wajib dilakukan oleh perempuan, tapi di Indonesia, perempuan boleh melakukan aksi teror karena laki-laki lebih pengecut." Hal itu terbaca dalam percakapan telegram pada Juni 2016. Faktor lain adalah karena perempuan dianggap lebih mudah dipengaruhi, terutama mereka yang memiliki masalah dalam keluarga.

Selain itu, kaum perempuan dianggap sangat loyal pada ajaran dan ideologi agama, lebih militan dalam menjalankan aksinya. Apalagi mereka yang pernah mengalami trauma, menjadi korban KDRT atau mengalami konflik dalam keluarga atau perceraian. Ketika dicuci otak dengan pemahaman radikal, para perempuan tersebut bisa dengan militan menjalankan misinya, bahkan lebih militan dari laki-laki.

Sejumlah alasan mengemuka mengapa perempuan terlibat. Pertama, disbanding laki-laki, mereka biasanya lebih leluasa bergerak dan tidak terlalu dicurigai oleh aparat keamanan sehingga nilai keterlibatan mereka jauh lebih tinggi di banding nilai keterlibatan teroris lawan jenisnya. Nilai khusus ini bertambah tinggi lagi belakangan ini karena kecurigaan terhadap kemungkinan aksi-aksi terorisme bunuh-diri juga meningkat pesat (Bloom, 2010).

Kedua, terlibatnya kaum perempuan sebagai pelaku bom bunuh-diri memiliki daya tarik tersendiri bagi media massa, terutama karena kini era digital, ketika laporan mengenai aksi-aksi seperti ini bukan saja bisa disampaikan lebih cepat tapi juga lebih hidup. Ini khususnya karena efek dramatis aksi-aksi yang menggunakan tubuh perempuan sebagai senjata, pada gilirannya akan memperkuat dan mempertebal makna perlawanan yang ditunjukkan oleh aksi-aksi teroris yang mereka wakili dan meningkatkan simpati kepada mereka (Nacos, 2005).

Ketiga, untuk lebih menggugah semangat para lelaki menjadi jihadis. Kalau perempuan saja bisa, maka kaum laki-laki harusnya lebih bisa. Ungkapan tersebut untuk memaksa kaum laki-laki lebih berani, meski melanggengkan stereotipe yangberlaku (Goldstein, 2003). Terakhir, dianggap sebagai indikator dari makin sejajarnya kedudukan perempuan dan laki-laki dalam masyarakat, terlepas dari apakah sang pelaku perempuan itu sendiri menyadari motif dasar perbuatan mereka atau tidak. Tidak sedikit dugaan bahwa mereka (sebagian diantaranya masih anak-anak) dimanipulasi oleh para pemimpin mereka yang umumnya laki-laki (Nacos, 2005).

Di Indonesia, pada 2015-2016 terdapat lebih dari 250 deportan yang separuhnya terdiri dari perempuandan anak-anak, kebanyakan mereka berangkat sekeluarga. Lalu, selama Januari-Maret 2017, jumlah deportan sudah mencapai lebih dari 140orang, dan 
79\% diantaranya adalah perempuan dan anak-anak. Mereka ditampung dipanti-panti yang disediakan Kementerian Sosial untuk diinterogasi.

\section{Status Sebagai Istri}

Umumnya perempuan yang terlibat aksi terorisme adalah para istri dari para lelaki yang berstatus sebagai suami mereka. Beberapa penelitian lain menyebutkan bahwa kelompok teroris global sekalipun diuntungkan dengan keterlibatan perempuan di dalamnya, bukan hanya sebagai perekrut melainkan sebagai sel propaganda gratis.

Di Indonesia, data Direktorat Jenderal Pemasyarakatan sampai Oktober 2016, jumlah narapidana terorisme sebanyak 223 orang. Sejak UU No. 15 Tahun 2003 tentang Terorisme berjalan sudah 9 perempuan dinyatakan terlibat dan memiliki peran dalam kejahatan terorisme, mereka adalah istri dari pelaku terorisme. Sementara itu, Direktorat Deradikalisasi Badan Nasional Penanggulangan Terorisme (BNPT) menyebut 51 orang istri pelaku terorisme yang akan disertakan dalam program deradikalisasi.

Kasus pelibatan perempuan sebagai isteri atau calon isteri dalam gerakan terorisme di Indonesia pertama kali terlihat dalam kasus Dian Yulia Novi. Dian mengaku mengalami proses indoktrinasi jihad qital melalui internet oleh suaminya, Nur Solihin. Nur Solihin sendiri merupakan anggota Bahrun Naim. Kasus ini mengemuka karena pertama kalinya pelibatan istri di Indonesia direkrut sebagai pelaku bom bunuh diri (suicide bomber), bahkan dengan modus pernikahan.

Kasus lainnya, dilakukan oleh Santoso yang melibatkan tiga istri pemimpin di kelompok tersebut untuk dibawa dan ikut bergerilya di dalam hutan guna melakukan perlawanan. Tidak hanya itu, fakta yang kemudian terkuak adalah kebutuhan biologis para pemimpin kelompok ini, yakni Santoso, Ali Kalora dan Basri yang menuntut para istri untuk ikut bergerilya. Hal ini dibuktikan dengan ditemukan barang bukti berupa pil KB dalam pengejaran aparat.

Sebelum fenomena pelibatan istri pelaku kejahatan terorisme di atas mengemuka, Pusat Kajian Radikalisme dan Deradikalisasi (PAKAR) meresume 9 isteri terlibat dalam kejahatan terorisme sampai tahun 2015 yang dirilis pada awal 2016. Enam di antaranya akhirnya menjalani proses peradilan pidana dengan dakwaan kasus teror, 2 di antaranya menjalani hukuman karena melanggar UU Keimigrasian, sementara sisanya bebas karena tidak terbukti ada keterkaitannya. Sembilan perempuan tersebut merupakan istri dari pelaku kejahatan terorisme, mereka yang terlibat adalah korban dari aktifitas teror yang dilakukan suaminya dan kelompok jaringan teroris yang menginginkan pendirian negara Islam.

Studi PAKAR menggambarkan betapa posisi istri dimanfaatkan oleh suami, seperti memberikan bantuan atau memenuhi kebutuhan suami dan kelompok mereka. Tidak hanya itu, sebagian besar istri akhirnya tidak tahu bahwa apa yang dilakukan 
dirinya atas perintah suaminya adalah bentuk bantuan untuk kelompok teroris, bahkan istri tidak mengetahui bahwa suaminya sebenarnya berafiliasi dengan kelompok teroris.

Studi ini juga menjelaskan bahwa istri para teroris tersebut, mengalami viktimisasi selama perjalanan hidupnya mulai dari proses penangkapan hingga sudah bebas dari jeruji besi, membuat mereka teralienasi dari keluarga, terkucilkan, rentan dan tidak mampu secara finansial karena tidak bisa mencari nafkah untuk keluarganya akibat pengucilan dan status mantan napi atau bahkan "janda teroris". Keberpihakan dan perlindungan negara terhadap para istri pelaku kejahatan terorisme sendiri juga terkesan masih tarik ulur.

Sebelum fenomena pelibatan istri pelaku kejahatan terorisme di atas mengemuka, Pusat Kajian Radikalisme dan Deradikalisasi (PAKAR) meresume 9 isteri terlibat dalam kejahatan terorisme sampai tahun 2015 yang dirilis pada awal 2016. Enam di antaranya akhirnya menjalani proses peradilan pidana dengan dakwaan kasus teror, 2 di antaranya menjalani hukuman karena melanggar UU Keimigrasian, sementara sisanya bebas karena tidak terbukti ada keterkaitannya. Sembilan perempuan tersebut merupakan istri dari pelaku kejahatan terorisme, mereka yang terlibat adalah korban dari aktifitas teror yang dilakukan suaminya dan kelompok jaringan teroris yang menginginkan pendirian negara Islam.

Studi PAKAR menggambarkan betapa posisi istri dimanfaatkan oleh suami, seperti memberikan bantuan atau memenuhi kebutuhan suami dan kelompok mereka. Tidak hanya itu, sebagian besar istri akhirnya tidak tahu bahwa apa yang dilakukan dirinya atas perintah suaminya adalah bentuk bantuan untuk kelompok teroris, bahkan istri tidak mengetahui bahwa suaminya sebenarnya berafiliasi dengan kelompok teroris.

Studi ini juga menjelaskan bahwa istri para teroris tersebut, mengalami viktimisasi selama perjalanan hidupnya mulai dari proses penangkapan hingga sudah bebas dari jeruji besi, membuat mereka teralienasi dari keluarga, terkucilkan, rentan dan tidak mampu secara finansial karena tidak bisa mencari nafkah untuk keluarganya akibat pengucilan dan status mantan napi atau bahkan "janda teroris". Keberpihakan dan perlindungan negara terhadap para istri pelaku kejahatan terorisme sendiri juga terkesan masih tarik ulur.

\section{Pola Peran Perempuan}

Peran perempuan dalam tindak terorisme terpola menjadi tiga bentuk. Pertama, sebagai pengikut dan pedamping setia suami. Peran perempuan sebagian besar masih pada tahapan domestifikasi perempuan. Artinya, mereka bukanlah aktor utama melainkan hanya sebagai istri, pengikut setia, dan ibu dari calon-calon teroris. Kedua, ahli propaganda dan agen perekrutan. Sejumlah perempuan dalam gerakan terorisme, seperti ISIS tidak diperbolehkan ikut bertempur di lapangan, melainkan hanya berperan, khususnya di media sosial, sebagai ahli propaganda, pendakwah, dan perekrut bagi ISIS 
dengan menerapkan pola rekruitmen yang mengandalkan hubungan pertemanan dan kekerabatan.

Setidaknya ada dua peran media sosial. Pertama, sebagai tempat bagi para perempuan untuk mengenal terorisme dan ideologinya, terhubung dengan sesama simpatisan atau dengan orang yang merekrut. Para perempuan ini bisa merekrut orangorang yang berpotensi sebagai pengikut, menyebarkan propaganda, maupun mobilisasi simpatisan. Kedua, media sosial mengungkap berbagai kegiatan perempuan yang terlibat dalam jaringan terorisme dan informasi ini menggiurkan banyak orang.

Ketiga, peran perempuan sebagai fighter atau bomber. Kelompok terorisme sering memanfaatkan perempuan, khususnya kulit putih sebagai pelaku bom bunuh diri. Hal itu karena stereotip Barat tentang pelaku teroris berasal dari negara-negara Muslim. Di Indonesia, perempuan pertama yang divonis sebagai pelaku bom bunuh diri adalah Dian Yulia Novi. Dia merencanakan serangan bom bunuh diri ke istana negara pada Minggu, 11 Desember 2016. Dian mengaku mengalami proses indoktrinasi jihad qital melalui internet yang dilakukan oleh sel propaganda teroris dan calon suaminya saat itu, Nur Solihin. Nur Solihin sendiri merupakan anggota jaringan dari Bahrun Naim. Kasus ini mengemuka karena pertama kalinya pelibatan istri di Indonesia direkrut untuk menjadi pelaku bom bunuh diri (suicide bomber) bahkan dengan modus pernikahan.

\section{Daya Tarik Terorisme Bagi Perempuan}

Pada 22 September 2016 aparat keamanan Indonesia di Bandara Soekarno-Hatta berhasil menggagalkan 7 warga negara Indonesia yang hendak berangkat ke Suriah untuk bergabung dengan ISIS, salah satunya perempuan yang diduga kuat sebagai penyandang dana. Ketertarikan dan minat para perempuan bergabung dalam gerakan terorisme memunculkan pertanyaan penting. Apa yang menarik bagi mereka sehingga berani mempertaruhkan nyawa mereka? Setidaknya ada empat faktor yang mendorong (Debbie, 2017).

Pertama, faktor religius. Elizabeth Pooley menemukan banyak Muslim di Inggris terpengaruh bergabung dengan ISIS karena mereka yakin bahwa: umat Islam sedang diserang; keinginan yang kuat untuk membangun sebuah masyarakat baru, bebas dari thagut (musuh-musuh Tuhan); kewajiban agama sebagai perempuan Muslim membela Islam dan kesempatan untuk menjadi bagian dan menemukan tujuan hidup bermakna dalam "persaudaraan perempuan khalifah" (caliphate sisterhood). Kedua, faktor ideologis. Para perempuan tertarik dengan ideologi terorisme yang militant dan terdengar kuat memperjuangkan keadilan. Ketiga, faktor politis. Kemiskinan, ketimpangan sosial, pelanggaran Hak Asasi Manusia, dan diskriminasi adalah narasi yang dikembangkan dalam gerakan terorisme dan bagi perempuan faktor-faktor itulah yang menyebabkan kepedihan mereka, yang kemudian memobilisasi potensial bagi kekerasan politik (political violence) melawan negara. 
Cara-cara radikal ekstrim yang dinarasikan oleh kelompok teroris telah banyak menarik kaum perempuan melakukan perlawanan terhadap kezaliman negara. Dalam konteks Indonesia, kekalahan secara politik bagi kelompok keagamaan garis keras, mendorong menguatnya gerakan terorisme yang dilakukan oleh orang-orang dari kelompok yang merasa termarjinalkan. Mereka biasanya menggunakan framing media bahwa negara abai terhadap kelompok yang secara nota bene menjadi mayoritas di negeri ini. Karena itu, sasaran tembak dari aksi-aksi terorisme adalah simbol-simbol atau institusi negara. Keempat, faktor pribadi. Berdasarkan kasus Shannon Conley, Anne Speckhard dalam bukunya Bride of ISIS (Spechkard, 2009). ISIS memotivasi perempuan muda Barat melalui internet dan membujuk mereka meninggalkan negaranya dan menjadi istri para jihadis atau menjadi teroris domestik di negara mereka sendiri.

\section{Perempuan hanyalah korban}

Telah banyak tesis yang menyakinkan bahwa perempuan selalu berada dalam posisi sebagai korban setiap suatu masyarakat mengalami proses radikalisasi dan fundamentalisasi. Perempuan dalam agama apa pun selalu menjadi sasaran pengendalian penafsir-penafsir fundamental yang benci pada perempuan (mysogini). Diskriminasi penafsiran, kata Karen Aemstrong dimulai ketika sejarah agama dipisahkan dari sejarah dan raison de etre keyakinan individu pemeluknya. Pergulatan agama hanya dipahami sebagai interior journey daripada sebagai sebuah sejarah dan drama politik sehingga terkesanlah teologi sebagai ilmu yang tertutup yang menghasilkan masyarakat agama yang tertutup. Tak ayal banyak konflik baik di tingkat global maupun nasional diakibatkan oleh teologi yang ekslusif.

Perempuan menjadi sasaran kelompok fundamentalisme agama karena mereka merasa memiliki legitimasi agama untuk melakukan itu. Legitimasi agama didukung pula oleh nilai-nilai yang secara umum memang berwatak patriarkis. Tidak mengherankan jika suatu masyarakat atau negara mengalami fundamentalisasi, domestifikasi dan semacamnya, perempuan biasanya menjadi program politik yang pertama. Mengapa demikian? Sebabnya adalah biaya sosial politik domestifikasi perempuan sangat murah dan mudah. Murah dan mudah karena dalam struktur masyarakat patriarki proyek domestifikasi perempuan tidak akan mendapat resistensi sosial politik yang berarti.

Pandangan fundamentalisme sangat membahayakan kehidupan perempuan. Sebab, umumnya pandangan mereka adalah menolak prinsip keadilan dan kesetaraan gender, menolak KB dan semua unsurnya, seperti menolak penggunaan alat-alat kontrasepsi. Mereka juga menolak pendidikan seksual dan kesehatan reproduksi sehingga para perempuan tidak mengerti hak-hak seksualitas dan kesehatan reproduksi, menolak penderita HIV/Aids dan kelompok Odha serta menganggap kutukan, menolak 
kelompok LGBT, menolak perlindungan thd korban perkosaan, menolak perlindungan terhadap pekerja seks komersial, dan tidak kurang bahayanya adalah mereka suka menganjurkan pernikahan anak dan poligami.

Masyarakat muslim yang mempertahankan fundamentalisme memiliki kecenderungan memanipulasi dan memanfaatkan ajaran Islam untuk melegitimasi kekuasaan patriarkhi dan mengucilkan perempuan dari ruang publik. Apabila mengamati secara umum hak-hak sipil dan politik kaum perempuan di bawah berbagai rezim Islam di dunia ini, terlihat secara kasat mata bahwa mereka sungguh membelenggu hak-hak sipil dan politik kaum perempuan. Konstitusi Islam Iran tahun 1979 setelah kemenangan revolusi misalnya, walaupun tidak secara eksplisit menunjukkan subordinasi perempuan sebagai warganegara kelas dua, dalam aktualisasinya telah membatasi hak-hak sipil dan politik kaum perempuan di wilayah publik (Ann, 1991).

Dengan alasan pemurnian agama dan kembali kepada teks Al-Qur'an dan Hadits, fundamentalisme Islam menegaskan perbedaan hak antara laki-laki dan perempuan. Menurut mereka, Tuhan sengaja membuat keduanya berbeda dan perbedaan itu bukan diskriminasi melainkan demi kebahagiaan manusia. Kesimpulannya, fundamentalisme mengajak kembali kepada agama. Akan tetapi, dalam konteks perempuan, apa yang mereka klaim sebagai upaya pemurnian agama adalah upaya domestifikasi perempuan. Ringkasnya, fundamentalisme memproklamirkan politik anti demokrasi, anti feminisme, anti pluralisme, dan anti humanisme.

\section{C.Simpulan}

1. Perlunya menguatkan kewibawaan pemerintah (eksekutif, yudikatif dan legislatif) dengan menegakkan nilai-nilai Pancasila, Konstitusi, demokrasi dan pemenuhan HAM.

2. Perlunya menguatkanpelaku ekonomi menegakkan keadilan sosial dan pemerataan kesejahteraan serta mencegah ketimpangan sosial-ekonomi.

3. Perlunya memperkuat jaringan kerjasama antar civil society dan berbagai elemen bangsa melalui kegiatan dialog kebangsaan, dialog kebudayaan, serta dialog antar-iman dan agama.

4. Perlunya memperbanyak diskusi dan dialog terbuka dengan kelompokkelompok radikal agar secara bertahap muncul kesepahaman di antara anak bangsa yang begitu beragam.

5. Perlunya memperbanyak program pendidikan kewarganegaraan yang berbasis kebhinnekaaan, toleransi dan pluralisme. 
6. Perlunya memperbanyak media yang sejuk dan bertanggungjawab, serta ramah terhadap perempuan dan kelompok rentan, mengedepankan nilai-nilai kesetaraan, keadilan dan perdamaian.

7. Perlunya memperbanyak tafsir keagamaan yang humanis dan kompatibel dengan nilai-nilai universal kemanusiaan, sejalan dengan ideologi Pancasila dan Konstitusi serta prinsip kesetaraan dan keadilan gender.

8. Perlunya menguatkan upaya pemuka agama mensosialisasikan ajaran agama yang humanis dan pluralis (konsep jihad, syahid, surga, rahmatan lil alamin).

9. Perlunya menguatkan masyarakat untuk berani bicara melawan ketidakadilan, intoleransi dan disriminasi serta mendorong mereka aktif menegakkan budaya damai.

\section{Referensi}

Alvanou, M. (2007). Palestinian Women Suicide Bombers: The Interplaying Effects of Islam, Nationalism and Honor Culture. Working Papers Series No.3. TelAviv, Israel: Strategic Research and Policy Center, National Defense College, IDF.

Bhakti, M. A. (2016). Perempuan dan Terorisme. Dikutip dari http://www.radicalismstudies.org/home/2015-04-19-13-02- 08/special-reportsand-analysis/270-perempuan-dan-terorisme.html.

Bloom, Mia. (2005). Dying to Kill: The Allure of Suicide Terror. New York: Columbia University Press.

Dariyanto, E. (2016). Santoso Pernah Perintahkan Pengikutnya Cari Pil KB da`n Pembalut Wanita. Dikutip dari detik.com. http://news.detik.com/berita/3179840/santoso-pernah perintahkan-pengikutnyacari-pil-kb-dan-pembalut-wanita.

Debbie, A. (2017). Reformulasi Ajaran Islam: Jihad, Khilafah, dan Terorisme. Jakarta: Mizan Pustaka, 341-342.

Djaka, S. (2010). Meniti Kalam Kerukunan; Beberapa Istilah Kunci Dalam Islam dan Kristen. Jakarta: PT BPK Gunung Mulia.

Kepala BNPT: UNdang-Undang Terorisme Indonesia Terlengkap di Dunia" dalam https://news.okezone.com/read/2018/05/26/340/1903139/kepala-bnpt-undang- 
undang-terorisme-indonesia-terlengkap-di-dunia diakses tanggal 17 Juli 2018, pukul 18.07.

Knop, K. (2007). The Female Jihad: Al-Qaida's Women. Studiesin Conflictand Terrorism, p.397-414.

Jordan, R. (2016). Ini Wajah 2 Terduga Teroris yang Antar Bom ke Calon 'Pengantin' Dian. Dikutip dari http://news.detik.com/berita/d-3369122/ini-wajah-2-terdugateroris-yang-antar-bom-ke-calon-pengantin-dian.

Laura Huey dan Eric Witner. (2016). Exploring a New Role for Women in Terrorism. Journal of Terorism Research, Vol. 7, No.1.

Nacos, B. (2005). Port rayal of Female Terrorists in the Media:Similar.

Siroj, S. A. (2017). Perempuan dan Terorisme. Dikutip dari Kompas.com: http://nasional.kompas.com/read/2017/01/06/12565011/perempuan.dan.terorism $\mathrm{e}$

Https://www.tempo.co/read/fokus/2016/12/15/3402/pola-rekrutmen-teroris-jadikanperempuan-sebagai-pengantin\#W2jOXFtUBprbOfxe.

$\mathrm{UU}$

Anti-Terorisme"

dalam

http://www.hukumonline.com/berita/baca/lt5b0531a3c651d/sekelumit-kisahperjalanan-uu-anti-terorisme diakses tanggal 17 Juli 2018, pukul. 17.05.

http://berkas.dpr.go.id/puslit/files/info_singkat/Info\%20Singkat-V-10-II-P3DI-Mei-

2013-46.pdf di akses tanggal 17 Juli 2018, pukul 13.38. 